\title{
Penicillium citrinum as a Potential Biocontrol Agent for Sisal Bole Rot Disease
}

\author{
Caroline Lopes Damasceno ${ }^{1}$, Jefferson Oliveira de Sá $^{2}$, Rafael Mota da Silva ${ }^{2}$, Cristiano Oliveira do Carmo ${ }^{3}$, \\ Lydice Sant'Anna Meira Haddad ${ }^{3}$, Ana Cristina Fermino Soares ${ }^{3} \&$ Elizabeth Amélia Alves Duarte ${ }^{3}$ \\ ${ }^{1}$ Biology Department, State University of Feira de Santana, Feira de Santana, Bahia, Brazil \\ ${ }^{2}$ Federal Institute for Education, Science and Technology Baiano, Bom Jesus da Lapa, Bahia, Brazil \\ ${ }^{3}$ Center for Agricultural, Environmental and Biological Sciences, Federal University of Reconcavo of Bahia, \\ Cruz das Almas, Bahia, Brazil
}

Correspondence: Elizabeth Amélia Alves Duarte, Center for Agricultural, Environmental and Biological Sciences, Federal University of Reconcavo of Bahia, 710, Rui Barbosa Street, Center, Cruz das Almas, Bahia, Zip Code 44380-000, Brazil. Tel: 55-753-621-9359. E-mail: elizabethaad@gmail.com

$\begin{array}{lcc}\text { Received: April 1, 2019 } & \text { Accepted: May 15, } 2019 & \text { Online Published: July 15, } 2019 \\ \text { doi:10.5539/jas.v11n10p206 } & \text { URL: https://doi.org/10.5539/jas.v11n10p206 }\end{array}$

\begin{abstract}
Agave sisalana, known as sisal, yields the world's main natural stiff fiber used to produce various industrial products. The Brazilian semiarid is the largest sisal producing region in the world; however, production is under threat by sisal bole rot disease, caused by Aspergillus welwitschiae. Since chemical control of this disease is questionable in drought-ridden areas with little investment in crop management and due to environmental and public health concerns, the search for a biocontrol agent against $A$. welwitschiae is warranted. In this work, we isolated and identificated Penicillium citrinum as an endophyte from sisal plants collected from the Brazilian semi-arid and investigated whether it could be a biocontrol agent against sisal bole rot. $P$. citrinum inhibited the mycelium growth of $A$. welwitschiae by $65.8 \%$ when inoculated 72 hours before the pathogen, in dual culture medium assays. We found that $P$. citrinum can reduce sisal bole rot disease up to $90 \%$ when inoculated in sisal plants 48 hours before pathogen inoculation. Altogether, our data suggest a potential role for P. citrinum in the control of sisal bole rot disease.
\end{abstract}

Keywords: biological control, Aspergillus welwitschiae, antagonism, sisal disease

\section{Introduction}

The global production of sisal fiber accounted for 247,000 tons with Brazil as the largest sisal producer (FAO, 2017). More than $95 \%$ of the Brazilian sisal is produced in the semi-arid region of the Bahia state, in the northeast of Brazil, being one of the main sources of employment and income (IBGE, 2016). The economic future of sisal is promising since it produces a natural fiber with several industrial and farm uses, some of them with an ecological appeal (Müssig, 2010). Sisal residues have been used in the production of organic fertilizers (Terrapon-Pfaff, Fischedick, \& Monheim, 2012), insecticides (Pizarro et al., 1999), nematicides (Damasceno, Soares, Jesus, \& Sant'Ana, 2015; Jesus et al., 2014), animal feed (Faria et al., 2008) and alcoholic beverages (Cantalino, Torres, \& Silva, 2015). The fiber can also be used in the bioenergy sector (soluble carbohydrates and lignocellulose) and substances extracted from the plant have antimicrobial, anti-inflammatory, antiseptic, and anti-parasitic functions (Davis, Kuzmick, Niechayev, \& Hunsaker, 2017; Sidana, Singh, \& Sharma, 2016; Yang et al., 2015).

Despite the economic relevance of sisal farming for the Brazilian semi-arid, the crop has been burdened by sisal bole rot disease (Suinaga, Silva, \& Coutinho, 2006), with 100\% prevalence and an average incidence of 35\% in sisal producing areas (Abreu, 2010). The disease symptoms are yellowish leaves are reddish discoloration of the stem tissue, with stem rotting that causes plant collapse and death (Coutinho, Suassuna, Luz, Suinaga, \& Silva, 2006). Recently, Aspergillus welwitschiae was reported as the causal agent of the sisal bole rot disease (Duarte et al., 2018). Black aspergilli (Aspergillus section Nigri) can cause diseases in several economically important crops such as tomatoes (Oladiran \& Iwu, 1993), onions (Gherbawy et al., 2015), garlic (Dugan, Hellier, \& Lupien, 2007), and peanuts (Palencia, Hinton, \& Bacon, 2010), among others. Considering the social and 
economic importance of the sisal fiber, it is essential to develop strategies to control bole rot disease in the Brazilian semi-arid region.

Interestingly, during the isolation of $A$. welwitschiae from sisal stem tissues with symptoms of brown rot, we frequently observed the emergence of fungal colonies characteristic of Penicillium sp. As some Penicillium species are reported to have antagonistic activity against phytopathogens (Ethur et al., 2005; Ma, Chang, Zhao, \& Zhou, 2008; Sempere \& Santamarina, 2010; Stefano, Nicoletti, Milone, \& Zambardino, 1999), we conjecture whether Penicillium sp. could be exploited as a biocontrol agent against $A$. welwitschiae. Since sisal is cultivated without agricultural management practices and based on small family farming systems, biological control may be promising in this pathosystem. Above all, biological control with antagonistic microorganisms has been studied and applied in population reduction and pathogen activity (Cook \& Baker, 1983; Heydari \& Pessarakli, 2010).

Therefore, the aims of this work were: i) to isolate the species of the Penicillium present in the diseased sisal stem tissues; ii) to identify the Penicillium sp. through molecular characterization; and iii) to evaluate the potential of the identified Penicillium sp. as a biocontrol agent against $A$. welwitschiae using assays performed in vitro and in vivo.

\section{Material and Methods}

\subsection{Fungal Cultures}

Penicillium sp. was isolated from the stem tissue of sisal plants with bole rot disease. Stem tissue fragments of approximately $1 \mathrm{~cm}$ of length and $0.5 \mathrm{~cm}$ of width were surface-sterilized through successive dipping in $70 \%$ ethanol $(1 \mathrm{~min}), 1 \%$ sodium hypochlorite $(1 \mathrm{~min})$, followed by washing with sterile distilled water $(1 \mathrm{~min})$ for three times in a laminar flow-hood, and were inoculated onto potato dextrose agar (PDA) medium (Pereira, Azevedo, \& Petrini, 1993; Petrini, 1986). These stems fragments were then incubated in a BOD type incubator at $25{ }^{\circ} \mathrm{C}$ for seven days, under dark conditions. After fungal growth took place, we recorded the colony morphology and transferred $0.5 \mathrm{~cm}$ diameter medium plugs containing the sporulated colonies to glass vials with sterile water for fungal preservation.

The pathogenic strain used in this study, the A. welwitschiae (CCMB 679), was isolated previously from sisal stem tissues with bole rot disease and deposited in the Coleção de Culturas de Microrganismos da Bahia (CCMB), of the State University of Feira de Santana (UEFS), Bahia, Brazil. This isolate was preserved in our laboratory at $-70{ }^{\circ} \mathrm{C}$ in cryogenic vials with glycerol $20 \%$ and as medium plugs with sporulated colonies in glass vials with sterile distilled water.

For the assays, the fungi were reactivated by transferring the agar plugs with the colonies to PDA medium to grow at $28{ }^{\circ} \mathrm{C}$ for seven days.

\subsection{Molecular Identification}

Total DNA extraction of the Penicillium sp. isolate was performed using the UltraClean ${ }^{\circledR}$ Microbial DNA Isolation kit (MoBio, USA), following the manufacturer's recommendations.

We analyzed two regions of the Internal Transcribed Spacer (ITS) with the pairs of primers ITS1 and ITS4 (White, 1990) and V9G and LS266 (Hoog \& Ende, 1998; Masclaux, Guého, De Hoog \& Christen, 1995), respectively; parts of the nuclear larger subunit (LSU) of the rDNA were used in the analysis with the primers LROR and LR5, as described by Vilgalys and Hester (1990). In addition, parts of the $\beta$-tubulin (BenA) with the primers Bt2a and Bt2b (Glass \& Donaldson, 1995) and RNA-polymerase II subunit (RPB2) with the primers 5F and 7CR (Liu, Whelen \& Hall, 1999). The reactions were prepared in a final volume of $50 \mu \mathrm{L}$ using the following reagents and concentrations: $60 \mathrm{ng}$ of DNA of each sample, $1 \times \mathrm{dAmpliTaq}_{\text {Gold }}^{\circledR} 360$ Master Mix (Life Technologies) and $0.5 \mathrm{pmol} / \mu \mathrm{L}$ of each primer (forward and reverse).

Amplified PCR products were purified with the Illustra ${ }^{\circledR}$ GFX PCR DNA and Gel Band Purification kit (GE Healthcare Life Sciences) and sequenced on an ABI3500 automated sequencer (Applied Biosystems, Life Technologies Q7, CA, USA). The sequences were edited using Geneious software, version 9.1.6 (Kearse et al., 2012) and deposited into the NCBI GenBank database.

The taxonomic identification of the Penicillium sp. isolate was verified in the GenBank database using the NCBI BLAST program (http://blast.ncbi.nlm.nih.gov/Blast.cgi).

\subsection{Antagonistic Action of Penicillium sp.}

The isolates of Penicillium sp. and A. welwitschiae were paired in the following two culture media laid on Petri plates: PDA and Czapek Yeast Agar (CYA). For this bioassay, inoculum of both fungi (mycelium plugs 
containing spores) were transferred, with a sterilized inoculating needle, to both media at two equidistant points $\left(1.5 \mathrm{~cm}\right.$ from the edge of the plate) and incubated at $28^{\circ} \mathrm{C}$. The treatments consisted of different time intervals $(0$, 24, 48 and $72 \mathrm{~h}$ ) between the inoculations of both fungi, as follows: first, Penicillium sp. was inoculated in all plates. Then, at times 0 (immediately after Penicillium sp. inoculation), 24, 48 and $72 \mathrm{~h}$ after inoculation with Penicillium sp., A. welwitschiae was inoculated. Penicillium sp. was given time advantage because it has a lower growth rate. The control consisted of inoculating only A. welwitschiae in both media. Each treatment had 10 replicates and each replicate consisted of one inoculated plate. Measurements of the A. welwitschiae colony diameter $(\mathrm{cm})$ were done, at 3-day intervals, until the pathogen reached the border of the plaques, for all treatments.

For data analysis, the percentage inhibition of mycelium growth was calculated using the following formula:

$$
\mathrm{Pi}=\{[(\text { Rcontr }- \text { Rtreat }) / \text { Rcontr }] \times 100\}-100
$$

where,

$\mathrm{Pi}=$ Percentage of inhibition; Rcontr $=$ radial growth of the control; Rtreat $=$ radial growth of the treatment (Menten, Machado, Minussi, Castro \& Kimati, 1976).

\subsection{Penicillium sp. Pathogenicity Test}

Sisal bulbils of $20 \mathrm{~cm}$ height and 90 days old were micro-wounded in the stem region at four equidistant points and inoculated by spraying with $2 \mathrm{~mL}$ of a spore suspension containing $10^{7}$ conidia $\mathrm{mL}^{-1}$ of Penicillium sp. The negative control consisted of spraying bulbils with distilled water, and the positive control consisted of spraying with the inoculum of the $A$. welwitschiae isolate with $10^{7}$ conidia $\mathrm{mL}^{-1}$. The plants were grown in a greenhouse and observed daily for external symptoms of bole rot disease. Three plants from each treatment were collected after 5 and 10 days of inoculation to search for internal disease symptoms and fungal colonization. Fourteen plants were maintained in the greenhouse to observe the development of disease symptoms for 30 days. Fragments of stem and root tissues were cut and treated with alcohol $70 \%(\mathrm{v} / \mathrm{v})$ for $2 \mathrm{~min}$, followed by sodium hypochlorite $1 \%(\mathrm{v} / \mathrm{v})$ for $2 \mathrm{~min}$, and three washes in sterilized distilled water (Pereira et al., 1993). The tissue fragments were transferred to a saline PDA medium $\left(6 \%\right.$ of $\mathrm{NaCl}$, w/v, supplemented with $1 \mathrm{~mL}^{-1}$ of oxytetracycline) and incubated in a BOD incubator at $28^{\circ} \mathrm{C}$ for seven days.

Evaluation of endophytic colonization by Penicillium sp. was carried out by counting the number of fragments of sisal root and stem tissues with mycelium growth. The frequency of colonized fragments was calculated considering the total number of plated fragments.

\subsection{Control of Bole Rot Disease by Penicillium sp. in Sisal Plants}

Sisal bulbils, planted in plastic bags with holes in the bottom and filled with $1 \mathrm{~kg}$ of soil, were micro-wounded in the stem region at four equidistant points and inoculated with Penicillium sp. by spraying it with $1 \mathrm{~mL}$ of spore suspension $\left(10^{7}\right.$ conidia $\left.\mathrm{mL}^{-1}\right)$. After inoculation with the antagonistic fungi, the sisal bulbils were inoculated with A. welwitschiae at time 0 (immediately after Penicillium sp. inoculation), and at 24, 48 and $72 \mathrm{~h}$ after Penicillium sp. inoculation). The positive control consisted of bulbils inoculated only with $A$. welwitschiae while the negative control consisted of bulbils treated with distilled water. The experimental design was randomized with 20 replications, with one bulbil (plant) per replication. Plants were maintained in the greenhouse and irrigated every three days.

Disease severity was evaluated 18 days after inoculation with $A$. welwitschiae according to the following scale: (0) no symptoms, (1) initial symptoms, (2) advanced symptoms, and (3) plant death (Figures 1A-1D). Mckinney infection index was determined (Mckinney, 1923) with the disease severity data. The IMC were determined by using the following formula:

$$
\mathrm{IMC} \%=[\Sigma(\mathrm{f} \times \mathrm{v}) / \mathrm{N} \times \mathrm{X}] \times 100
$$

where,

$\mathrm{f}=$ infection class (notes) frequencies; $\mathrm{v}=$ number of plants in each class; $\mathrm{N}=$ total of plants observed; $\mathrm{X}=$ highest value in evaluation scale. 


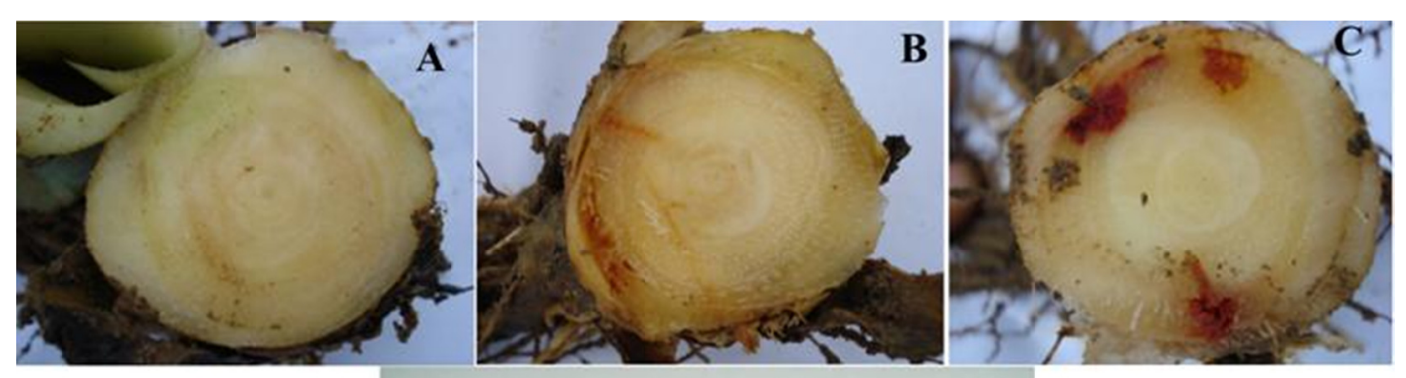

D

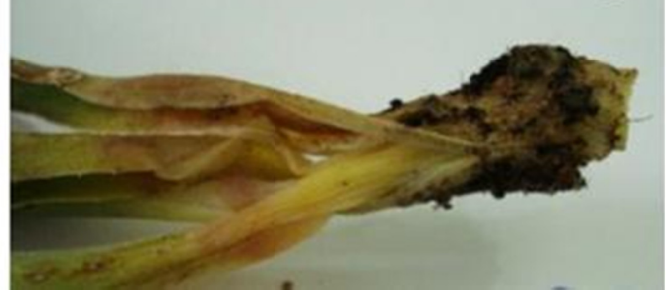

Figure 1. Scale of the severity of bole rot disease in sisal plants: (A) Healthy plant-note 0; (B) Initial symptom-note 1; (C) Advanced symptom-note 2 and (D) Dead plant-note 3

\subsection{Statistical Analysis}

The data were analyzed using variance analysis (ANOVA) and, when significant, means comparison were performed by the Tukey test $(\mathrm{p} \leq 0.05)$ using the software Sisvar version 5.6 (Ferreira, 2014).

Maximum-likelihood trees (Tamura, Steche, Peterson, Filipski \& Kumar, 2013) of Jukes-Cantor model (Jukes \& Cantor, 1969) were constructed for the major taxonomic groups to confirm the taxonomic affiliations of the sequences obtained and to investigate their phylogenetic diversity. Phylogenetic analyses were built using MEGA6 (Tamura et al., 2013). The bootstrap values were calculated from 1000 replicates.

\section{Results}

\subsection{Molecular Identification of Penicillium sp.}

The sequences obtained using the primers ITS 1-4, ITS V9G-LS266, LSU, BenA and RPB2 were resolved phylogenetically as Penicillium and identified as P. citrinum (Figures 2A-2D, respectively). The Penicillium citrinum sequences was deposited on GenBank database (NCBI) under the following accession numbers: MH665232 (ITS1-4), MH665233 (V9G-LS266), MH665234 (LSU), MH665235 (BenA) and MH665236 (RPB2). 
A

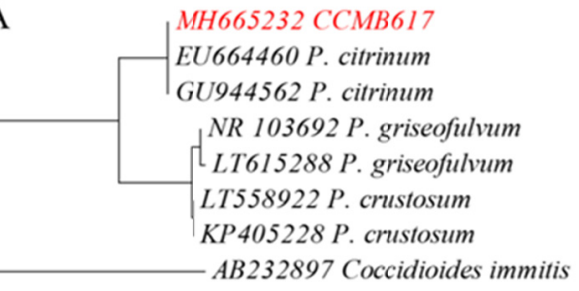

$\mathrm{B}$

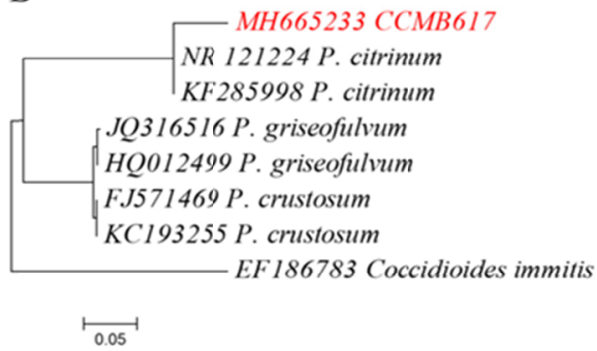

C

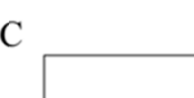

$\square$

MH665234 CCMB617

AB284185 P.citrinum

IN938950 P.citrinum

KY859382 P. griseofulvum

AY373917 P. griseofulvum

MG009431 P. crustosum

KY906188 P. crustosum

XM 001246167 Coccidioides immitis

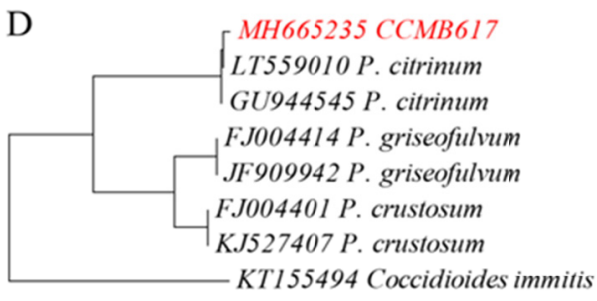

E $\stackrel{\bullet}{0.05}$

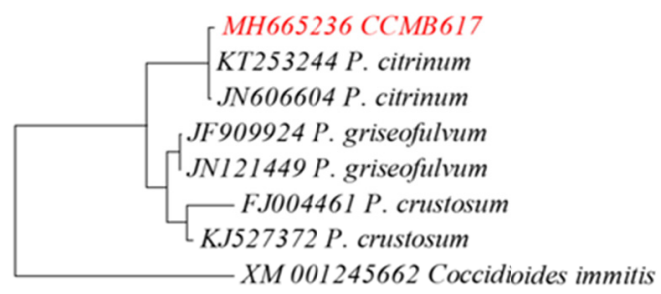

$\stackrel{.05}{0.05}$

$\stackrel{\leftrightarrow .05}{0.05}$

Figure 2. Maximum Likehood (ML) phylogenetic trees generated for ITS 1-4 (A); ITS V9G-LS266 (B); LSU (C); BenA (D) and RPB2 (E) using the evolutionary model of Jukes-Cantor. Species of Penicillium crustosum

(LT558922; KP405228; FJ571469; KC193255; MG009431; KY906188; FJ004401; KJ527407; FJ004461;

KJ527372); Penicillium griseofulvum (NR103692; LT615288; JQ316516; HQ012499; KY859382; FJ004414; JF909942; JF909924; JN121449) Coccidioides immitis (AB232897; EF186783; XM001246167; KT155494;

XM001245662) were used as outgroups. About $50 \%$ of the bootstrap values are shown among branches supported by 1000 replicates.

The culture of the P. citrinum was deposited in the Coleção de Culturas de Microrganismos da Bahia (CCMB) at the Universidade Estadual de Feira de Santana, Bahia, Brazil, under the following code: CCMB617.

\subsection{Antagonistic Action of Penicillium citrinum}

The pairing of both fungi on CYA and PDA culture media showed that $P$. citrinum inhibited the growth of $A$. welwitschiae in both media $(p=0.0001)$ and at all tested time intervals $(p=0.0001)$ (Figure 3A). In the PDA medium, $A$. welwitschiae growth inhibition was not significantly altered considering the different time intervals between inoculation of the antagonist and the pathogen $(p=0.1095)$. Fungi inoculated in the CYA medium revealed the best results at the inoculation intervals of 24 and $72 \mathrm{~h}$, with $72 \mathrm{~h}$ being the best time interval for $A$. welwitschiae growth inhibition (65.8\%) (Figure 3A). In addition, CYA medium promoted the best mycelium growth for both fungi. Indeed, A. welwitschiae reached the plate borders 12 days after incubation in CYA medium and 18 days in PDA medium. Figure 3B illustrates fungal growth inhibition in CYA and PDA media at 12 and 18 days of incubation. 
A)

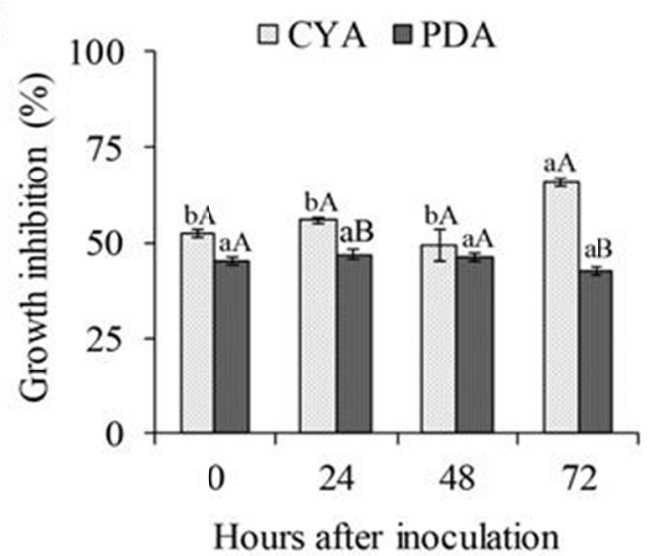

B)

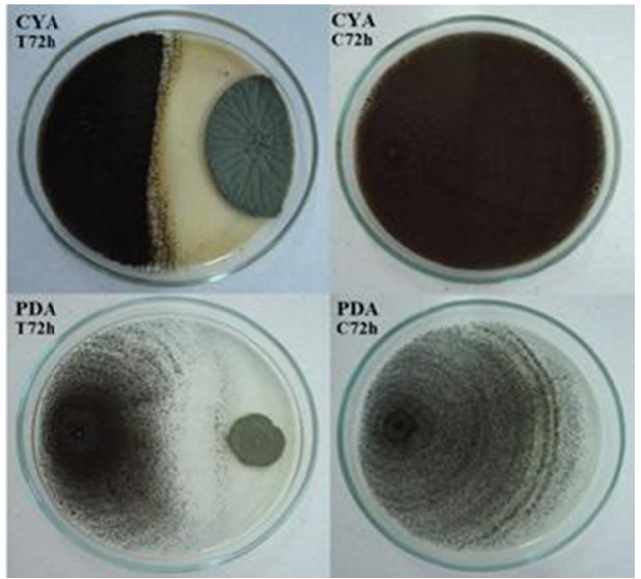

Figure 3. Antagonistic action of Penicillium citrinum: A) Inhibition of mycelial growth (\%) of Aspergillus welwitschiae in response to antagonism from Penicillium citrinum in Czapek Yeast Agar (CYA) and Potato Dextrose Agar (PDA) culture media, at intervals of 0,24, 48 and 72h, between inoculations. Means followed by distinct letters differ by the Tukey test at the $5 \%$ probability; lowercase letters represent differences between culture media and uppercase letters represent differences between hours after inoculation. B) Antagonism in vitro between $P$. citrinum (greenish culture) and $A$. welwitschiae (black culture), paired in CYA and PDA at interval of $72 \mathrm{~h}$ between inoculations and negatives controls treatments: BDA C72h and CYA C72h. Pictures of treatments in culture media after 12 days of incubation for CYA and 18 days for PDA which correspond to end of the evaluations when $A$. welwitschiae reached the edge of the plates

\subsection{Penicillium Citrinum Pathogenicity Test}

Bulbils inoculated with $P$. citrinum did not show any detectable rotting symptoms, indicating that this fungus is not pathogenic to sisal. Five days after stem inoculation, P. citrinum colonized $90 \%$ of the root and $50 \%$ of the stem tissues. No significant difference $(p=0.0045)$ in the stem colonization rate was observed between 5 and 10 days after inoculation of sisal stems with $P$. citrinum.

\subsection{Control of Bole Rot Disease by Penicillium citrinum in Sisal Plants}

Simultaneous inoculation of sisal plants with $P$. citrinum and A. welwitschiae did not promote a reduction in bole rot severity and this treatment was similar to the positive control, which consisted of plants inoculated only with the pathogen (Figure 4). The time intervals starting at $24 \mathrm{~h}$ between plant inoculation with $P$. citrinum and $A$. welwitschiae were efficient in reducing disease severity in $65 \%$. Plants inoculated with the pathogen at $48 \mathrm{~h}$ and $72 \mathrm{~h}$ after $P$. citrinum inoculations had a disease incidence of only $10 \%$. The results for these treatments were similar to those observed for the negative control treatment, with plants that received only distilled water (Figure 4). Indeed, these treatments did not show statistical differences in disease incidence, confirming the potential of P. citrinun for controlling sisal bole rot disease when plants are inoculated before infection by the pathogen. 


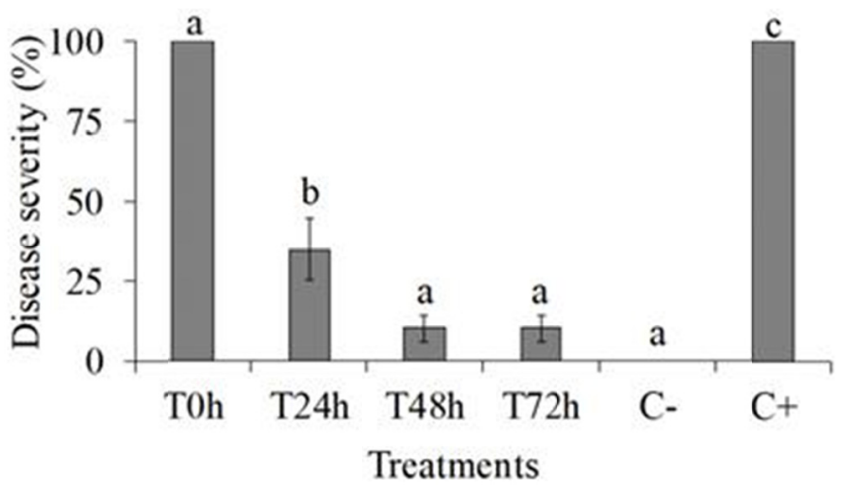

Figure 4. Severity of bole rot disease in sisal plants treated with Penicillium citrinum at different time intervals: 0 , 24, 48 and $72 \mathrm{~h}$, before pathogen application, under field conditions. C-: Negative control treatment with sterilized distilled water; $\mathrm{C}+$ : Positive control treatment with Aspergillus welwitschiae. Evaluations were done 30 days after the inoculation either with A. welwitschiae and P. citrinum. Averages of 20 replicates are shown. Means followed by the same letter do not differ significantly according to Tukey's test at $5 \%$ probability

\section{Discussion}

In this study we show that $P$. citrinum is an endophytic fungus of Agave sisalana plants and a promising biological control agent against the sisal bole rot disease caused by A. welwitschiae, not pathogenic to sisal plants. Our data demonstrate that this antagonistic fungal isolate is not pathogenic to sisal plants, co-exists in the same environment where the disease occurs, and colonizes the internal stem tissues of sisal, which is an important trait of efficient biocontrol agents (Fravel, 2005).

The high rate of bole colonization by $P$. citrinum reported herein may be related to its preference for this tissue due to the presence of sugars (Fisher, Petrini \& Scott, 1992) and the fact that the architecture of the sisal root makes hampers root fungal penetration and colonization (Cunha Neto \& Martins, 2012).

Previous studies showed that members of the genus Penicillium could have antagonistic effects against several plant pathogens. Indeed, some species formulated for this use presented effective responses (Ma et al., 2008; Sabuquillo, De Cal \& Melgarejo, 2010; Sempere \& Santamarina, 2010). However, an accurate identification of the species from the Penicillium genus that can be used for biocontrol is necessary because many species are pathogenic in humans, animals, and plants (Oh, Kim, Ryoo \& Kim, 2008; Samson, Seifert, Kuijpers, Houbraken \& Frisvad, 2004; Samson, Houbraken, Varga \& Frisvad, 2009; Peterson, Orchard \& Menon, 2011; Varga et al., 2011). Some Penicillium species inhibit plant diseases by releasing volatile compounds and secondary metabolites as well as other control mechanisms (Geiser et al., 2006; Houbraken \& Samson, 2011; Samson et al., 2009). The genus Penicillium is known to produce specific secondary metabolites including alkaloids and mycotoxins such as citrinin, which is characteristic of $P$. citrinum, as well as other polyketides with antimicrobial activity (Houbraken, Frisvad \& Samson, 2010; Kim, Park \& Lee, 2012; Lai, Brötz-Oesterhelt, Müller, Wray \& Proksch, 2013; Malmstrøm, Christophersen \& Frisvad, 2000).

The production of metabolites by microorganisms is influenced by their culture conditions such as available nutrients, the incubation time, and the fungal growth phase (Elias, Said, de Albuquerque \& Pupo, 2006; Lattab, Kalai, Bensoussan \& Dantigny, 2012). Therefore, it is important to define the best culture conditions for the antagonism of $P$. citrinum against $A$. welwitschiae. Under in vitro conditions, antagonism was best in CYA medium at a time interval of $72 \mathrm{~h}$ between the inoculation of $P$. citrinum and the inoculation of $A$. welwitschiae. The antagonistic microorganism needs optimal conditions to produce secondary metabolites (Heydari \& Pessarakli, 2010). Thus, the lack of antagonistic effect of $P$. citrinum against the pathogenic A. welwitschiae observed when they were inoculated at the same time (time $0 \mathrm{~h}$ ) suggests that there was probably not enough time for $P$. citrinum to produce the necessary metabolites to affect the pathogenic fungi. Indeed, growth inhibition zones varied depending on the time between fungi inoculation (Figure 3B).

Understanding the mechanisms of antagonism between fungi is an important step for the development of models aiming at introducing microorganisms for biological control in agricultural ecosystems (Heydari \& Pessarakli, 2010; Oliveira et al., 2015). The production of secondary metabolites by P. citrinum with antagonistic effect against $A$. welwitschiae suggests antibiosis as a possible mechanism. Another mechanism likely to be occurring is competition for nutrients and space since in the in vitro experiments both fungi used the same substrate for 
growth.

The role of $P$. citrinum as the biological control agent (BCA) of fungal pathogens through plant/endophyte interactions was shown in sunflower (Helianthus annuus L.) with stem rot caused by Alternaria alternata (Waqas et al., 2015a) and by Sclerotium rolfsii (Waqas et al., 2015b). P. citrinum isolated from the coastal sand dunes of South Korea and its flora was also found to promote plant growth by activating gibberellin production, which was considered important for the conservation and revegetation of these stressful environments (Khan et al., 2008).

The semi-arid region in Bahia, Brazil, where sisal has been produced for fiber extraction for several decades is a stressful environment subject to high temperatures, high UV radiation, and drought conditions. Sisal has been produced in this region of Brazil mostly in family-based farming systems without the use of agricultural inputs or adequate soil management practices, in areas with sandy and sandy loam soils (Table 1). Under these conditions, $P$. citrinum may have an important role as a soil fungus and plant endophyte with growth promoting, stress alleviating, and biocontrol traits that can contribute to the growth of this economically important crop in this harsh environment.

\section{Conclusion}

Herein we found that $P$. citrinum CCMB617 is an endophyte of sisal plants and a soil inhabitant adapted to the semiarid region of Bahia, Brazil, where sisal has been grown for decades. We found that $P$. citrinum is a potential biocontrol agent against $A$. welwitschiae, the causing agent of sisal bole rot disease, when inoculated at 48 and 72 hours before the plant's contact with the pathogen, causing mycelium growth inhibition.

We believe that it is possible to use $P$. citrinum in the nursery phase of sisal plant propagation to produce plants colonized by $P$. citrinum as a disease-prevention strategy. Future research should investigate the mechanisms underlying the antagonistic action of $P$. citrinum and the secondary metabolites involved in this process to effectively harness this trait in favor of sisal production.

\section{References}

Abreu, K. C. L. D. M. (2010). Epidemiologia da podridão Vermelha do Sisal no Estado da Bahia (Ph.D. thesis, Universidade Federal do Recôncavo da Bahia, Brazil). Retrieved from http://www.repositorio.ufrb.edu.br

Cantalino, A., Torres, E. A. \& Silva, M. S. (2015). Sustainability of Sisal cultivation in Brazil using co-products and wastes. Journal of Agricultural Science, 7(7), 64. https://doi.org/10.5539/jas.v7n7p64

Cunha Neto, I. L., \& Martins, F. M. (2012). Anatomia dos órgãos vegetativos de Agave sisalana Perrine Ex Engelm (Agavaceae). Revista Caatinga, 25, 72-78.

Damasceno, J. C., Soares, A. C., Jesus, F. N., \& Sant'Ana, R. S. (2015). Sisal leaf decortication liquid residue for controlling Meloidogyne javanica in tomato plants. Horticultura Brasileira, 33, 155-162. https://doi.org/ 10.1590/S0102-053620150000200004

Davis, S. C., Kuzmick, E. R., Niechayev, N., \& Hunsaker, D. J. (2017). Productivity and water use efficiency of Agave americana in the first field trial as bioenergy feedstock on arid lands. Global Change Biology Bioenergy, 9, 314-325. https://doi.org/10.1111/gcbb.12324

Duarte, E. A. A., Damasceno, C. L., Oliveira, T. A. S. D., Barbosa, L. D. O., Martins, F. M., Silva, J. R. D. Q., ... Soares, A. C. F. (2018). Putting the mess in order: Aspergillus welwitschiae (and not A. niger) is the etiological agent of sisal bole rot disease in Brazil. Frontiers in Microbiology, 9, 1227. https://doi.org/ 10.3389/fmicb.2018.01227

Dugan, F. M., Hellier, B. C., \& Lupien, S. L. (2007). Pathogenic fungi in garlic seed cloves from the United States and China, and efficacy of fungicides against pathogens in garlic germplasm in Washington State. Journal of Phytopathology, 155, 437-445. https://doi.org/10.1111/j.1439-0434.2007.01255.x

Cook, R. J., \& Baker, K. F. (1983). The Nature and Practice of Biological Control of Plant Pathogens. Minnesota, EUA: The American Phytopathological Society.

Coutinho, W. M., Suassuna, N. D., Luz, C. M., Suinaga, F. A., \& Silva, O. R. (2006). Bole rot of sisal caused by Aspergillus niger in Brazil. Fitopatologia Brasileira, 31, 605. https://doi.org/10.1590/S0100-41582 006000600014

Elias, B. C., Said, S., de Albuquerque, S., \& Pupo, M. T. (2006). The Influence of culture conditions the biosynthesis of secondary metabolites by Penicillium verrucosum Dierck. Microbiological Research, 161, 273-280. https://doi.org/10.1016/j.micres.2005.10.003 
Ethur, L. Z., Blume, E., Muniz, M., Silva, A. D., Stefanelo, D. R., \& Rocha, E. D. (2005). Fungos antagonistas a Sclerotinia sclerotiorum em pepineiro cultivado em estufa. Fitopatologia Brasileira, 30, 127-133. https://doi.org/10.1590/S0100-41582005000200004

FAO. (2017). Future Fibres, Sisal plant. Food and Agriculture Organization of the United Nations Database. Retrieved from http://www.fao.org/economic/futurefibres/fibres/sisal/en

Faria, M. M. S., Jaeger, S. M. P. L., Oliveira, G. J. C., Oliveira, R. L., Ledo, C. A. S., \& Santana, F. S. (2008). Composição bromatológica do coproduto do desfibramento do sisal tratado com ureia. Revista Brasileira de Zootecnia, 37, 377-382. https://doi.org/10.1590/S1516-35982008000300001

Ferreira, D. F. (2014). Sisvar: A Guide for its Bootstrap procedures in multiple comparisons. Ciência e Agrotecnologia, 38, 109-112. https://doi.org/10.1590/S1413-70542014000200001

Fisher, P. J., Petrini, O., \& Scott, H. L. (1992). The distribution of some fungal and bacterial endophytes in maize (Zea mays L.). New Phytologist, 122, 299-305. https://doi.org/10.1111/j.1469-8137.1992.tb04234.x

Fravel, D. R. (2005). Commercialization and implementation of biocontrol. Annual Review of Phytopathology, 43, 337-359. https://doi.org/10.1146/annurev.phyto.43.032904.092924

Gherbawy, Y., Elhariry, H., Kocsubé, S., Bahobial, A., Deeb, B. E., Altalhi, A., ... Vágvölgyi, C. (2015). Molecular characterization of black Aspergillus species from onion and their potential for ochratoxin A and fumonisin B2 production. Foodborne Pathogens and Disease, 12(5), 414-423. https://oi.org/10.1089/ fpd.2014.1870

Geiser, D. M., Gueidan, C., Miadlikowska, J., Lutzoni, F., Kauff, F., Hofstetter, ... Aptroot, A. (2006). Eurotiomycetes: Eurotiomycetidae and Chaetothyriomycetidae. Mycologia, 98, 1053-1064. https://doi.org/ 10.1080/15572536.2006.11832633

Glass, N. L., \& Donaldson, G. C. (1995). Development of premier sets designed for use with the PCR to amplify conserved genes from filamentous Ascomycetes. Applied and Environmental Microbiology, 61, 1323-1330.

Heydari, A., \& Pessarakli, M. (2010). A Review on Biological Control of Fungal Plant Pathogens Using Microbial Antagonists. Journal of Biological Sciences, 10, 273-290. https://oi.org/10.3923/ jbs.2010.273.290

Hoog, G. D., \& Ende, A. H. G. (1998). Molecular diagnostics of clinical strains of filamentous Basidiomycetes. Mycoses, 41, 183-189. https://doi.org/10.1111/j.1439-0507.1998.tb00321.x

Houbraken, J. A., Frisvad, J. C., \& Samson, R. A. (2010). Taxonomy of Penicillium citrinum and related species. Fungal Diversity, 44, 117-133. https://doi.org/10.1007/s13225-010-0047-z

Houbraken, J., \& Samson, R. A. (2011). Phylogeny of Penicillium and the segregation of Trichocomaceae into three families. Studies in Mycology, 70, 1-51. https://doi.org/10.3114/sim.2011.70.01

IBGE (Instituto Brasileiro de Geografia e Estatística). (2016). Levantamento Sistemático da produção agrícola. Retrieved from ftp://ftp.ibge.gov.br/producao_agricola/levantamento_sistematico_da_producao_agricola [mensal]/fasciculo/2016/lspa_201612_20170222_133000.pdf

Jesus, F. N., Damasceno, J. C., Barbosa, D. H., Malheiro, R., Pereira, J. A., \& Soares, A. C. (2014). Control of the banana burrowing nematode using sisal extract. Agronomy for Sustainable Development, 35, $783-791$. https://doi.org/10.1007/s13593-014-0264-z

Jukes, T. H., \& Cantor, C. R. (1969). Evolution of protein molecules. Mammalian protein metabolism. New York: Academic Press.

Kearse, M., Moir, R., Wilson, A., Stones-Havas, S., Cheung, M., Sturrock, S., ... Drummond, A. (2012). Geneious Basic: an integrated and extendable desktop software platform for the organization and analysis of sequence data. Bioinformatics, 28, 1647-1649. https://doi.org/10.1093/bioinformatics/bts199

Khan, S. A., Hamayun, M., Yoon, H., Kim, H. Y., Suh, S. J., Hwang, S. K., .. Kim, J. G. (2008). Plant growth promotion and Penicillium citrinum. BMC Microbiology, 8(1), 231. https://doi.org/10.1186/ $1471-2180-8-231$

Kim, H. Y., Park, H. M., \& Lee, C. H. (2012). Mass spectrometry based chemotaxonomic classification of Penicillium species (P. echinulatum, P. expansum, P. solitum, and P. oxalicum) and its correlation. The Journal of Microbiological Methods, 90, 327-335. https://doi.org/10.1016/j.mimet.2012.06.006

Lai, D., Brötz-Oesterhelt, H., Müller, W. E., Wray, V., \& Proksch, P. (2013). Bioactive polyketides and 
alkaloids from Penicillium citrinum, a fungal endophyte isolated from Ocimum tenuiflorum. Fitoterapia, 91, 100-106. https://doi.org/10.1016/j.fitote.2013.08.017

Lattab, N., Kalai, S., Bensoussan, M., \& Dantigny, P. (2012). Effect of storage conditions (relative humidity, duration, and temperature) on the germination time of Aspergillus carbonarius and Penicillium chrysogenum. The International Journal of Food Microbiology, 160, 80-84. https://doi.org/10.1016/ j.ijfoodmicro.2012.09.020

Liu, Y. J., Whelen, S., \& Hall, B. D. (1999). Phylogenetic relationships among ascomycetes: Evidence from an RNA polymerse II subunit. Molecular Biology and Evolution, 16, 1799-1808. https://doi.org/10.1093/ oxfordjournals.molbev.a026092

Ma, Y., Chang, Z. Z., Zhao, J. T., \& Zhou, M. G. (2008). Antifungal activity of Penicillium striatisporum Pst10 and its biocontrol effect on Phytophthora root rot of chilli pepper. Biological Control, 44, $24-31$. https://doi.org/10.1016/j.biocontrol.2007.10.005

Malmstrøm, J., Christophersen, C., \& Frisvad, J. C. (2000). Secondary metabolites characteristic of Penicillium citrinum, Penicillium steckii and related species. Phytochemistry, 54, 301-309. https://doi.org/10.1016/ S0031-9422(00)00106-0

Masclaux, F., Guého, E., De Hoog, G. S., \& Christen, R. (1995). Phylogenetic relationships of human pathogenic Cladosporium xylohypha species inferred from partial LS rRNA sequences. Journal of Medical and Veterinary Mycology, 33, 327-338. https://doi.org/10.1080/02681219580000651

Menten, J. O. M., Machado, C. C., Minussi, E., Castro, C., \& Kimati, H. (1976). Efeito de alguns fungicidas no crescimento micelial de Macrophomina phaseolina (Tass.) Goid. "in vitro". Fitopatologia Brasileira, 1, 57-66.

Mckinney, H. H. (1923). Influence of soil, temperature and moisture on infection of wheat seedlings by Helminthosporium sativum. The Journal of Agricultural Reseach, 26, 195-217.

Müssig, J. (2010). Industrial applications of natural fibres: Structure, properties and technical applications. Chichester, UK: John Wiley \& Sons, Ltda. https://doi.org/10.1002/9780470660324

Oh, J. Y., Kim, E. N., Ryoo, M. I., \& Kim, K. D. (2008). Morphological and Molecular Identification of Penicillium islandicum isolate KU101 from Stored Rice. The Plant Pathology Journal, 24, 469-473. https://doi.org/10.5423/PPJ.2008.24.4.469

Oladiran, A. O., \& Iwu, L. N. (1993). Studies on the fungi associated with tomato fruit rots and effects of environment on storage. Mycopathologia, 1(21), 157-161. https://doi.org/10.1007/BF01104071

Oliveira, T. A. S., Duarte, E. A. A., Silva, R. M., Moreira, Z. P. M., Carmo, C. O., \& Luz, E. D. M. N. (2015). Biocontrole de doenças pós-colheita em frutas. Revisão Anual de Patologia de Plantas, 23, 293-325.

Palencia, E. R., Hinton, D. M., \& Bacon, C. W. (2010). The black Aspergillus species of maize and peanuts and their potential for mycotoxin production. Toxins, 2, 399-416. https://doi.org/10.3390/toxins2040399

Pereira, J. O., Azevedo, J. L., \& Petrini, O. (1993). Endophytic fungi of Stylosanthes. Mycologia, 85, $362-364$. https://doi.org/10.2307/3760696

Peterson, S. W., Orchard, S. S., \& Menon, S. (2011). Penicillium menonorum, a new species related to $P$. pimiteouiense. IMA Fungus, 2, 121-125. https://doi.org/10.5598/imafungus.2011.02.02.02

Petrini, O. (1986). Taxonomy of endophytic fungi of aerial plant tissues. In N. J. Fokkema (Ed.), Microbiology of the Phyllosphere. Cambridge: Cambridge University Press.

Pizarro, A. P. B., Oliveira Filho, A. M., Parente, J. P., Melo, M. T., Santos, C. E. D., \& Lima, P. R. (1999). Utilization of the waste of sisal industry in the control of mosquito larvae. Revista da Sociedade Brasileira de Medicina Tropical, 32(1), 23-29. https://doi.org/10.1590/S0037-86821999000100005

Sabuquillo, P., De Cal, A., \& Melgarejo, P. (2010). Development of a dried Penicillium oxalicum conidial formulation for use as a biological agent against Fusarium wilt of tomato: Selection of optimal additives and storage conditions for maintaining conidial viability. Biological Control, 54, 221-229. https://doi.org/ 10.1016/j.biocontrol.2010.05.010

Samson, R. A., Seifert, K. A., Kuijpers, A. F., Houbraken, J. A. M. P., \& Frisvad, J. C. (2004). Phylogenetic analysis of Penicillium subgenus Penicillium using partial $\beta$-tubulin sequences. Studies in Mycology, 49, 175-200. 
Samson, R. A., Houbraken, J., Varga, J., \& Frisvad, J. C. (2009). Polyphasic taxonomy of the heat resistant Ascomycete genus Byssochlamys and its Paecilomyces anamorphs. Persoonia, 22, 14-27. https://doi.org/10.3767/003158509X418925

Sempere, F., \& Santamarina, M. P. (2010). Study of the interactions between Penicillium oxalicum Currie \& Thom and Alternaria alternata (fr.) Keissler. Brazilian Journal of Microbiology, 41, 700-706. https://doi.org/10.1590/S1517-83822010005000021

Sidana, J., Singh, B., \& Sharma, O. P. (2016). Saponins of Agave: Chemistry and bioactivity. Phytochemistry, 130, 22-46. https://doi.org/10.1016/j.phytochem.2016.06.010

Stefano, S., Nicoletti, R., Milone, A., \& Zambardino, S. (1999). 3-o-Methylfunicone, a fungitoxic metabolite produced by the fungus Penicillium pinophilum. Phytochemistry, 52, 1399-1401. https://doi.org/10.1016/ S0031-9422(99)00320-9

Suinaga, F. A., Silva, O. R. R. F., \& Coutinho, W. M. (2006). Cultivo de sisal na região Semi-árida do Nordeste Brasileiro. Campina Grande, PB: Embrapa Algodão.

Tamura, K., Stecher, G., Peterson, D., Filipski, A., \& Kumar, S. (2013). MEGA6: Molecular Evolutionary Genetics Analysis version 6.0. Molecular Biology and Evolution, 30, 2725-2729. https://doi.org/10.1093/ molbev/mst197

Terrapon-Pfaff, J. C., Fischedick, M., \& Monheim, H. (2012). Energy potentials and sustainability-the case of sisal residues in Tanzania. Energy for Sustainable Development, 16(3), 312-319. https://doi.org/10.1016/ j.esd.2012.06.001

Varga, J., Frisvad, J. C., Kocsubé, S., Brankovics, B., Tóth, B., Szigeti, G., \& Samson, R. A. (2011). New and revisited species in Aspergillus section Nigri. Studies in Mycology, 69, 1-17. https://doi.org/10.3114/ $\operatorname{sim} .2011 .69 .01$

Vilgalys, R., \& Hester, M. (1990). Rapid genetic identification and mapping of enzymatically amplified ribosomal DNA from several Cryptococcus species. Journal of Bacteriology, 172, 4238-4246. https://doi.org/10.1128/jb.172.8.4238-4246.1990

Waqas, M., Khan, A. L., Hamayun, M., Shahzad, R., Kim, Y. H., Choi, K. S., \& Lee, I. J. (2015a). Endophytic infection alleviates biotic stress in sunflower through regulation of defence hormones, antioxidants and functional amino acids. European Journal of Plant Pathology, 141, 803-824. https://doi.org/10.1007/ s10658-014-0581-8

Waqas, M., Khan, A. L., Hamayun, M., Shahzad, R., Kang, S. M., Kim, J. G., \& Lee, I. J. (2015b). Endophytic fungi promote plant growth and mitigate the adverse effects of stem rot: An example of Penicillium citrinum and Aspergillus terreus. Journal of Plant Interactions, 10, 280-287. https://doi.org/10.1080/ 17429145.2015 .1079743

White, T. J., Bruns, T., Lee, S. J. W. T., \& Taylor, J. L. (1990). Amplification and direct sequencing of fungal ribosomal RNA genes for phylogenetics. In M. A. Innis, D. H., Gelfand, J. J. Sninsky, \& T. J. White (Eds.), PCR protocols: A guide to methods and applications. New York: Academic Press. https://doi.org/10.1016/ B978-0-12-372180-8.50042-1

Yang, X., Cushman, J. C., Borland, A. M., Edwards, E. J., Wullschleger, S. D., Tuskan, G. A., ... Holtum, J. A. M. (2015). A roadmap for research on crassulacean acid metabolism (CAM) to enhance sustainable food and bioenergy production in a hotter, drier world. New Phytologist, 207, 491-504. https://doi.org/ 10.1111/nph.13393

\section{Copyrights}

Copyright for this article is retained by the author(s), with first publication rights granted to the journal.

This is an open-access article distributed under the terms and conditions of the Creative Commons Attribution license (http://creativecommons.org/licenses/by/4.0/). 